УДК 577.1:661.29:577.112.3:599.323.4

DOI 10.11603/mcch.2410-681X.2019.v0.i1.10028

В. М. Нечипорук ${ }^{1}$, Н. В. Заічко ${ }^{1}$, А. В. Мельник ${ }^{1}$, О. Б. Струтинська ${ }^{1}$, М. М. Корда ВІННИЦЬКИЙ НАЦІОНАЛЬНИЙ МЕДИЧНИЙ УНІВЕРСИТЕТ IMЕНІ М. І. ПИРОГОВА ТЕРНОПІЛЬСЬКИЙ ДЕРЖАВНИЙ МЕДИЧНИЙ УНІВЕРСИТЕТ ІМЕНІ І. Я. ГОРБАЧЕВСЬКОГО

\title{
ОСОБЛИВОСТІ ВПЛИВУ ГІПЕРГОМОЦИСТЕЇНЕМІЇ НА МЕТАБОЛІЗМ СІРКОВМІСНИХ АМІНОКИСЛОТ У ПЕЧІНЦІ ЩУРІВ 3 РІЗНОЮ ФУНКЦЕЮ ЩИТОПОДІБНОЇ ЗАЛОЗИ
}

Вступ. Гомоцистеїн (ГЦ) - сірковмісна амінокислота, що утворюється при нормальному біосинтезі амінокислот метіоніну та цистеїну. Відомо, що гормони щитоподібної залози мають значний вплив на фуункцї серцево-судинної системи. Високий ризик розвитку серцево-судинних захворювань існує в пацієнтів з гіпергомоцистеїнемією (ГГЦ). Рівень ГЦ у хворих з гіпотиреозом вищий, ніж у здорових людей. Водночас незрозуміло, чи пов'язаний розвиток серцево-судинних захворювань у пацієнтів з патологією щитоподібної залози зі змінами вмісту в крові ГЦ.

Мета дослідження - встановити вплив експериментальної гіпергомоцистеїнемії на процеси обміну сірковмісних амінокислот у тварин з гіпер- та гіпотиреозом.

методи дослідження. Дослідження виконано на білих щурах-самцях, в яких моделювали гіпергомоцистеїнемію, гіпер-та гіпотиреоз. У печінці визначали активність S-аденозилметіонінсинтетази (S-AMS), S-аденозилгомоцистеїнгідролази (S-AГГ), бетаїнгомоцистеїнметилтрансфрерази (БГМT), цистатіонін- $\beta$-синтази (ЦБС), цистатіонін-у-ліази (ЦГЛ), цистеїнамінотрансорерази (ЦАТ), $\gamma$-глутамілцистеїнлігази (у-ГЦЛ), цистеїндіоксигенази (ЦДО), сульфітоксидази (СО), у сироватці крові - загальний вміст ГЦ, цистеїну, $\mathrm{H}_{2} \mathrm{~S}$.

Результати й обговорення. Тривала ГГЦ призводила до пригнічення активності ензимів утилізації ГЦ у печінці (БГМТ, S-AMS, S-АГГ), деградації цистеїну (ЦДО, у-ГЦЛ, СО) та синтезу $\mathrm{H}_{2}$ S (десульфуразна активність ЦБС, ЦГЛ), що викликало істотне підвищення в сироватці крові рівня ГЦ і цистеїну та зменшення вмісту $\mathrm{H}_{2} \mathrm{~S}$. Гіпертиреоз зумовлював зростання активності більшості ензимів циклу реметилування (БГМT, S-AMS, S-АГГ), десульфурування (ЦБС, ЦГЛ), посилення окиснення цистеїну (ЦДО, у-ГЦЛ, CO), зменшення рівня ГЦ і цистеїну та збільшення вмісту $\mathrm{H}_{2} \mathrm{~S}$ у крові. Паралельне введення L-тироксину тваринам із ГГЦ призводило до зниження активності ензимів циклу реметилування (БГMT, S-AMS, S-AГГ), транссульфрування (ЦДО, у-ГЦЛ, СО) та десульфурування (ЦБС, ЦГЛ), водночас спостерігали позитивну динаміку щодо зменшення вмісту ГЦ і цистеїну та зростання рівня $\mathrm{H}_{2} \mathrm{~S}$ у крові. Гіпотиреоз викликав зниження в печінці активності ензимів циклу реметилування (БГMT, S-AMS, S-АГГ) і процесів транссульфрування (ЦБС, ЦГЛ, ЦАТ), збільшення вмісту ГЦ і цистеїну та зменшення рівня $\mathrm{H}_{2} \mathrm{~S}$. Паралельне введення мерказолілу тваринам із ГГЦ зумовлювало зростання концентрації ГЦ у сироватці крові щурів, що є наслідком порушення реакцій циклу метилування (S-AMC, S-АГГ, БГМТ) і десульфурування (ЦБС, ЦГЛ, ЦАТ) в печінці тварин з експериментальною ГГЦ.

Висновки. Збільшення вмісту ГЦ і цистеїну, зменшення рівня $\mathrm{H}_{2} \mathrm{~S}$ можуть бути вагомими фракторами ризику розвитку атеросклерозу, оксидативного стресу, ендотеліальної дисфуннкії та гіперкоагуляції при хворобах, що супроводжуються зниженням рівня тиреоїдних гормонів. Отримані дані є передумовою для подальших експериментальних досліджень, направлених на поліпшення розуміння механізмів формування патологічних станів, асоційованих з порушеннями обміну сірковмісних амінокислот при гіпергомоцистеїнемії і розладах функції щитоподібної залози, та оптимізації підходів до їх фрармакотерапії.

КЛЮЧОВІ СЛОВА: тиреоїдні гормони; сірковмісні амінокислоти; цикл реметилування; шлях транссульфування; гомоцистеїн; цистеїн; гідроген сульфід.

ВСТУП. Гомоцистеїн (ГЦ) - непротеїногенна сірковмісна амінокислота, що утворюється при нормальному біосинтезі амінокислот метіоніну та цистеїну [1]. Велика кількість досліджень показала, що він є незалежним фрактором ризику розвитку серцево-судинних, аутоімунних захворювань та запальних процесів [2, 3].

( ) В. М. Нечипорук, Н. В. Заічко, А. В. Мельник, О. Б. Струтинська, М. М. Корда, 2019.
Відомо, що гормони щитоподібної залози мають значний вплив на фрункції серцево-судинної системи. У пацієнтів із захворюваннями щитоподібної залози існує високий ризик розвитку серцево-судинних патологій. Гіпертиреоз призводить до багатьох змін у серцево-судинній системі, а саме: зростання частоти серцевих скорочень, скоротливості міокарда та фрракції викиду, систолічної гіпертонії, систолічних шу- 
мів, збільшення маси лівого шлуночка і розвитку стенокардії, фрібриляції передсердь з ризиком інсульту $[4,5]$. Пацієнти із субклінічним гіпертиреозом також мають підвищений ризик розвитку фрібриляції передсердь [6]. Встановлено, що порушення з боку щитоподібної залози призводить до розвитку миготливої аритмії, а також атеросклерозу та інфраркту міокарда [7]. 3 іншого боку, дефіцит гормонів щитоподібної залози спричиняє зниження частоти серцевих скорочень і послаблення скорочення міокарда та його релаксації [7-9].

Нещодавно проведені дослідження показали, що може існувати двонаправлений зв'язок між ГЦ та імунозапальною активацією, при якому імунозапальна активація може сприяти збільшенню рівня ГЦ, у свою чергу, ГЦ може взаємодіяти з ушкодженими тканинами як прозапальна та імуностимулювальна молекула [10]. Було встановлено позитивний зв'язок між концентрацією ГЦ та деякими біогуморальними параметрами запалення, такими, як рівні цитокінів, С-реактивного білка та молекул адгезії [11]. Останні дослідження показали, що рівень ГЦ у пацієнтів 3 гіпотиреозом вищий, ніж у хворих 3 гіпертиреозом [12]. У пацієнтів 3 хворобою Хашимото встановлено значно вищий рівень ГЦ у крові [13]. Хвороба Грейвса є одним з найпоширеніших аутоімунних захворювань щитоподібної залози, що викликає гіпертиреоз. Пацієнти із цією хворобою мають підвищену схильність до серцево-судинних патологій, водночас незрозуміло, чи пов'язаний даний імунозапальний стан зі змінами рівня у крові ГЦ.

Мета дослідження - встановити вплив експериментальної гіпергомоцистеїнемії на процеси обміну сірковмісних амінокислот у тварин з гіпер- та гіпотиреозом.

МЕТОДИ ДОСЛІДЖЕННЯ. Для досліджень використано 48 безпородних щурів-самців масою 150-180 г, яких утримували на стандартному раціоні з 12-годинним режимом день/ніч. Воду та гранульований корм тварини отримували ad libitum відповідно до нормативів [14].

Усіх тварин поділили на 6 груп. До 1-ї групи (контрольної) входили інтактні щури (тваринам внутрішньошлунково вводили розчин $1 \%$ крохмального гелю), до 2-ї - щури з тіолактоновою гіпергомоцистеїнемією (ГГЦ), яку створювали шляхом введення в організм тварин надлишку екзогенного ГЦ у вигляді тіолактону (тіолактон гомоцистеїну (тіолактон-ГЦ) вводили внутрішньошлунково в дозі 100 мг/кг маси тіла на $1 \%$ розчині крохмалю один раз на добу протягом 28-ми діб; дозу, шляхи і тривалість введення тіолактон гомоцистеїну запозичено з літератур- них джерел при проведенні подібних досліджень, вони не викликали загибелі тварин [15]); до 3-ї щури з гіпертиреозом, яким щоденно протягом 21-ї доби вводили внутрішньошлунково L-тироксин у дозі 200 мкг/кг на $1 \%$ розчині крохмалю (доза, шляхи і тривалість введення L-тироксину ґрунтуються на результатах попередніх досліджень і не викликали загибелі тварин [16]); до 4-ї - щури з тіолактоновою ГГЦ, яким щоденно протягом 21-ї доби вводили внутрішньошлунково L-тироксин у дозі 200 мкг/кг на $1 \%$ розчині крохмалю; до 5-ї-тварини з гіпотиреозом, яким щоденно протягом 21-ї доби вводили внутрішньошлунково мерказоліл у дозі 10 мг/кг на $1 \%$ розчині крохмалю [16]; до 6-ї - тварини з тіолактоновою ГГЦ, яким щоденно протягом 21-ї доби вводили внутрішньошлунково мерказоліл у дозі 10 мг/кг на $1 \%$ розчині крохмалю.

При дослідженні впливу модуляторів біохімічних процесів тварин виводили з експерименту через 24 год після останнього введення обраних речовин. Для дослідів використовували плазму крові, тканину печінки. Дослідження проведено згідно із загальними етичними принципами експериментів на тваринах.

Печінку перфузували холодним 1,15 \% розчином калію хлориду і гомогенізували при 3000 об./хв у середовищі 1,15 \% калію хлориду (співвідношення 1:3). Гомогенати центрифругували впродовж 30 хв при $1500 \mathrm{~g}$ та $+4{ }^{\circ} \mathrm{C}$. У печінці визначали активність S-аденозилметіонінсинтетази (S-AMC, КФ 2.5.1.6) [17], S-аденозилгомоцистеїнгідролази (S-АГГ, КФ 3.3.1.1) [18], бетаїнгомоцистеїнметилтрансферази (БГМТ, КФ 2.1.1.5) [19], цистатіонін- $\beta$-синтази (ЦБС, КФ 4.2.1.22), цистатіонін-ү-ліази (ЦГЛ, КФ 4.4.1.1) і цистеїнамінотрансорерази (ЦАТ, КФ 2.6.1.3) [20]. Активність у-глутамілцистеїнлігази (у-ГЦл, КФ 6.3.2.2) визначали за кількістю утвореного неорганічного фоссфату, що утворювався при гідролізі АТФ у реакції між глутаматом і цистеїном [21]. Активність цистеїндіоксигенази (ЦДО, КФ 1.13.11.20) оцінювали за зменшенням вмісту цистеїну адаптованим методом [22]. Активність сульфітоксидази (СО, КФ 1.8.3.1) в печінці визначали за швидкістю окиснення сульфіт-аніона за присутності калій гексоціанофрерату [23].

У сироватці крові визначали загальний вміст ГЦ імуносрерментним методом з використанням набору фірми "Axis-Shield" (Велика Британія). Рівень загального цистеїну визначали за реакцією з нінгідриновим реактивом у кислому середовищі після відновлення цистину в цистеїн [22]. Вміст $\mathrm{H}_{2} \mathrm{~S}$ у сироватці крові визначали за реакцією утворення тіоніну із застосуванням $\mathrm{N}, \mathrm{N}$-диметил-р-френілендіаміну [24]. Статистичний аналіз проводили, використовуючи стан- 
дартні статистичні програми i t-критерій Стьюдента. Результати виражали як середнє \pm SEM 3 8-ми експериментів. Зміни $p<0,05$ розглядали як статистично достовірні.

РЕЗУЛЬТАТИ Й ОБГОВОРЕННЯ. ГОМОЦИСтеїн може бути повторно метильований до метіоніну (реакція каталізується S-аденозилметіонінсинтетазою) чи реметильований сролатнезалежним ензимом бетаїнгомоцистеїнметилтрансферазою. Він може також бути незворотно метаболізований шляхом транссульфування ензимом цистатіонін- $\beta$-синтазою з утворенням цистеїну. Цистеїн, у свою чергу, метаболізується двома шляхами. Це синтез глутатіону з участю ензиму у-глутамілцистеїнлігази або реакція окиснення з участю цистеїндіоксигенази з утворенням цистеїнсульфрінату. В реакції трансамінування цистеїнсульфінат з участю цистеїнсульфрінатамінотрансферази (КФ 2.6.1.75) перетворюється на $\beta$-сульфрінілпіруват, далі - на сульфріт, що окиснюється до сульфрату сульфрітоксидазою. Сульсріти та сульфрати є субстратами для синтезу глікозаміногліканів. Також у цьому шляху обміну цистеїну утворюється біологічно активна сполука - таурин. Порушення метаболізму ГЦ внаслідок генетичної зміни в метаболічних ензимах метіонінсинтазі, метилтетрагідрофолатредуктазі, цистатіонін- $\beta$-синтазі, цистатіонін-у-ліазі та цистеїнамінотрансферазі або дефріцит кофакторів (вітамінів $\mathrm{B}_{6}, \mathrm{~B}_{12}, \mathrm{~B}_{9}$ ) можуть призвести до набутої метаболічної аномалії - гіпергомоцистеїнемії.

Встановлено, що тривале введення тіолактон гомоцистеїну супроводжувалося зменшенням швидкості утилізації ГЦу циклі метилування в щурів (табл. 1). Зокрема, показано сповільнення реакції активації метіоніну з участю S-AMC на 20,5\% порівняно 3 контрольною групою тварин. Гіпертиреоз призводив до зростання активності S-AMC на 35 та $69 \%$ порівняно 3 контрольною групою і тваринами з ГГЦ. Введення L-тироксину щурам із ГГЦ викликало зниження активності S-AMC на 37 \% порівняно з групою тварин, яким вводили L-тироксин. Встановлено, що у тварин, в яких викликали гіпотиреоз, активність ензиму достовірно (на 31 \%) зменшувалась порівняно 3 контрольною групою. Паралельне введення мерказолілу щурам із ГГЦ зумовлювало зниження активності S-AMC порівняно 3 контрольною групою, проте при статистичному аналізі зміни виявилися недостовірними. Також при ГГЦ на $24 \%$ зменшилась відносно контролю швидкість синтезу S-аденозилгомоцистеїну 3 участю S-АГГ. Введення L-тироксину призводило до протилежних змін, а саме зростала активність S-АГГ на 33 та 76 \% порівняно 3 контрольною групою і тваринами з ГГЦ. Введення L-тироксину щурам із тривалою ГГЦ спричиняло зниження активності S-АГГ на 32 \% порівняно 3 групою тварин із гіпертиреозом. Подібно до ГГЦ, введення мерказолілу тваринам викликало пригнічення активності S-АГГ на 25 \% проти контролю. Паралельне введення мерказолілу щурам із ГГЦ призводило до зменшення активності S-АГГ на 60 та 48 \% відповідно проти контрольної групи і тварин, в яких викликали ГГЦ і гіпотиреоз.

При експериментальній ГГЦ на 25 \% зменшувалося утворення метіоніну з ГЦ і бетаїну 3 участю БГМТ порівняно з контрольною групою. За умов гіпертиреозу активність БГМТ зростала на 45 та 93 \% порівняно з контрольною групою і тваринами з ГГЦ. Паралельне введення L-тироксину щурам із ГГЦ викликало зниження активності БГМТ на 43 \% порівняно з контролем. Експериментальний гіпотиреоз призводив до зниження активності БГМТ на 43 та $24 \%$ проти контрольної групи і тварин із ГГЦ. Активність БГМТ достовірно (на 46 та 28 \%) зменшувалась при паралельному введенні мерказолілу порівняно $з$ контрольною групою і щурами, в яких викликали ГГЦ.

Таблиця 1 - Активність (нмольхв'мг протеїну) ензимів циклу метилування в печінці щурів

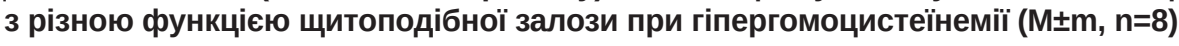

\begin{tabular}{|c|c|c|c|c|c|c|}
\hline \multirow{5}{*}{ Показник } & \multicolumn{6}{|c|}{ Група тварин } \\
\hline & \multirow{4}{*}{ інтактні } & модель ГГЦ & $\begin{array}{c}\text { модель } \\
\text { гіпертиреозу }\end{array}$ & $\begin{array}{c}\text { модель } \\
\text { гіпертиреозу+ } \\
\text { гГЦ }\end{array}$ & $\begin{array}{c}\text { модель } \\
\text { гіпотиреозу }\end{array}$ & $\begin{array}{c}\text { модель } \\
\text { гіпотиреозу+ } \\
\text { гГЦ }\end{array}$ \\
\hline & & \multicolumn{5}{|c|}{ час від початку введення, доби } \\
\hline & & тіолактон-ГЦ & L-тироксин & $\begin{array}{l}\text { L-тироксин i } \\
\text { тіолактон-ГЦ }\end{array}$ & мерказоліл & $\begin{array}{l}\text { мерказоліл і } \\
\text { тіолактон-ГЦ }\end{array}$ \\
\hline & & 28 & 21 & 28 & 21 & 28 \\
\hline S-AMC & $5,83 \pm 0,45$ & $4,66 \pm 0,27^{*}$ & $7,88 \pm 0,52^{* \&}$ & $4,96 \pm 0,25^{\#}$ & $4,02 \pm 0,38^{*}$ & $4,36 \pm 0,35$ \\
\hline S-АГГ & $5,65 \pm 0,32$ & $4,27 \pm 0,40$ & $7,53 \pm 0,50$ *\& & $5,09 \pm 0,22^{\#}$ & $4,26 \pm 0,35^{\star}$ & $2,24 \pm 0,28 * \& \$$ \\
\hline БГМТ & $8,65 \pm 0,50$ & $6,46 \pm 0,45^{\star}$ & $12,50 \pm 0,95^{\star \&}$ & $7,09 \pm 0,34^{\#}$ & $4,94 \pm 0,29 * \&$ & $4,65 \pm 0,40$ *\& \\
\hline
\end{tabular}

Примітка. Тут і в таблицях 2-4 зміни достовірні: * - порівняно з інтактними тваринами; \& - порівняно з групою щурів, яким вводили тіолактон-ГЦ; * - порівняно з групою тварин, яким вводили L-тироксин; ${ }^{\$}-$ порівняно з групою щурів, яким вводили мерказоліл. 
Після проведення дослідження також було встановлено зміни активності ензимів десульфуразного шляху утилізації цистеїну (табл. 2), що $є$ джерелом важливої біологічно активної молекули $-\mathrm{H}_{2} \mathrm{~S}$. Введення протягом 28-ми діб тіолактон-ГЦ призводило до зниження десульфруразної активності ЦБС на 21 \% відносно контролю. Моделювання експериментального гіпертиреозу в щурів-самців спричиняло підвищення активності ЦБС на $46 \%$ порівняно 3 групою тварин із ГГЦ. Паралельне введення L-тироксину щурам із ГГЦ викликало її зростання на $26 \%$ щодо тварин із ГГЦ. Активність ЦБС при гіпотиреозі достовірно знижувалася на 33 \% порівняно $з$ контрольною групою тварин. Подібні результати отримали також Xu, Yan та ін. (2018) [25], які продемонстрували, що гіпотиреоз, спричинений тиреоектомією, зумовлює експресію ЦБС, ЦГЛ та зменшення рівня $\mathrm{H}_{2} \mathrm{~S}$ у крові. Паралельне введення тваринам мерказолілу і тіолактон-ГЦ призводило до значного (на 68 та 52 \%) зниження активності ЦБС порівняно $з$ інтактними тваринами і щурами, в яких викликали гіпотиреоз. Подібні зміни спостерігали також щодо активності ензиму ЦГЛ. Моделювання експериментальної ГГЦ спричиняло ії̈ зменшення на 25 \% порівняно з інтактними тваринами. Натомість гіпертиреоз, навпаки, призводив до зростання активності ЦГЛ на 43 \% відносно щурів, у яких викликали ГГЦ. Введення L-тироксину тваринам із ГГЦ не спричиняло негатив- них змін активності ЦГЛ, вона була нижчою, відповідно, на 40, 25 та 30 \% порівняно 3 контрольною групою тварин і групою щурів, у яких викликали ГГЦ та гіпертиреоз відповідно. Активність ЦГЛ при гіпотиреозі достовірно (на 33 \%) знижувалась щодо контрольної групи тварин. При паралельному введенні мерказолілу щурам із ГГЦ вона зменшувалась у 2,8 та 1,9 раза порівняно з інтактними тваринами та групою щурів з гіпотиреозом. Експериментальна ГГЦ призводила до зниження активності ЦГЛ на 21 \%. Гіпотиреоз достовірно (на 38 \%) зменшував активність ЦГЛ щодо контрольної групи тварин. Введення мерказолілу тваринам із ГГЦ спричиняло достовірне (на 40 та 25 \%) зниження активності ЦГЛ порівняно $з$ контрольною групою тварин і групою щурів, у яких моделювали ГГЦ.

Очевидно, такий напрямок змін активності ензимів циклу реметилування логічно повинен призвести до змін вмісту ГЦ, цистеїну та рівня $\mathrm{H}_{2} \mathrm{~S}$. Щоденне введення тваринам протягом 28-ми діб тіолактон-ГЦ викликало стан постійної ГГЦ (табл. 3), що підтверджувалося збільшенням концентрації ГЦу крові щурів на 28-му добу в 3,6 раза. Концентрація загального цистеїну при цьому достовірно зростала (на 28-му добу на $34 \%$ ). Рівень $\mathrm{H}_{2} \mathrm{~S}$ достовірно знижувався на 28-му добу експерименту на $26 \%$. Введення тваринам протягом 21-ї доби L-тироксину викликало зменшення вмісту ГЦ у сироватці крові на 23 \% порівняно 3 контрольною групою тварин

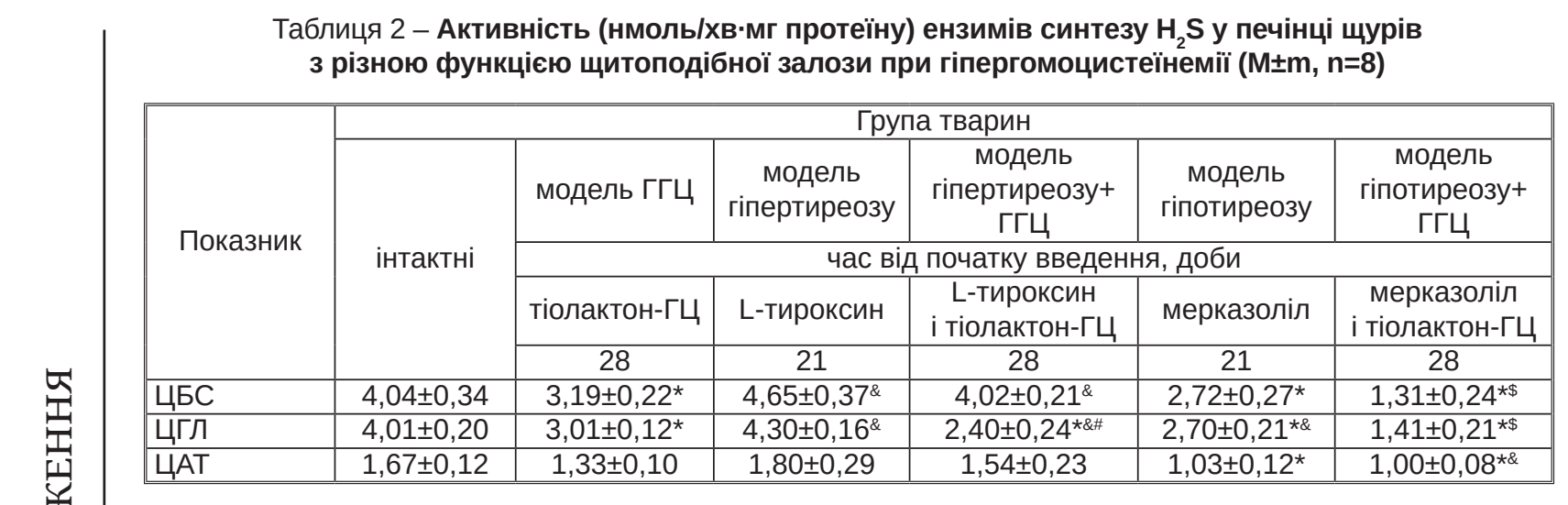

Таблиця 3 - Вміст (мкмольл) цистеїну, гомоцистеїну, $\mathrm{H}_{2} \mathrm{~S}$ у сироватці крові щурів

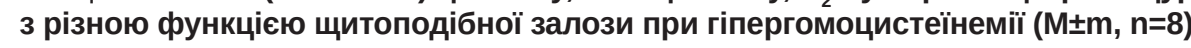

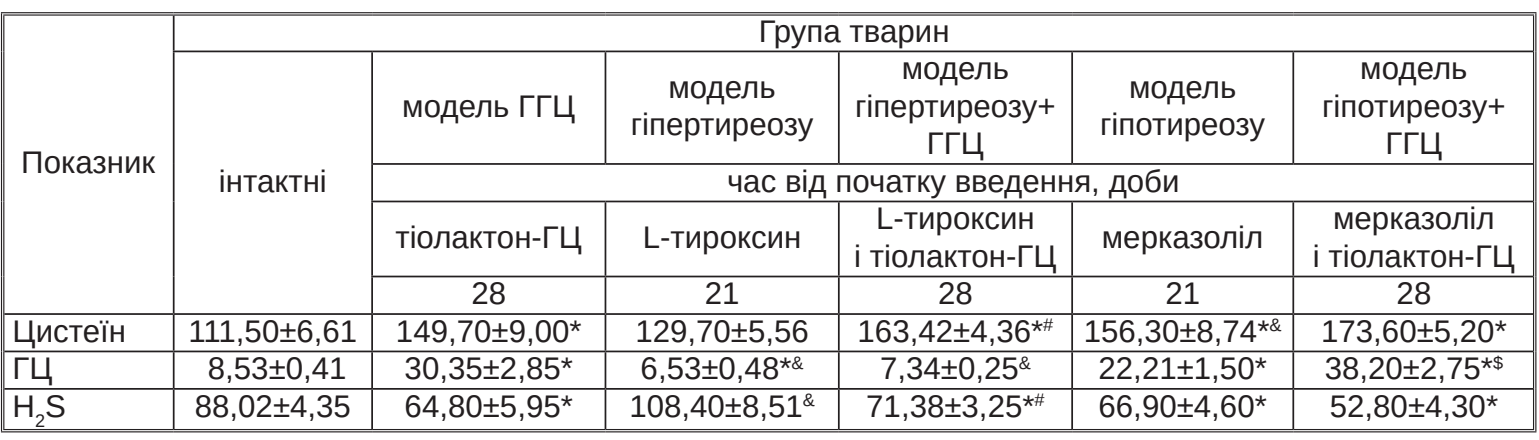


і на 78 \% щодо щурів, яким вводили тіолактон-ГЦ.

Моделювання гіпертиреозу спричиняло зростання рівня $\mathrm{H}_{2} \mathrm{~S}$ порівняно 3 контрольною групою тварин, але при статистичному аналізі дані виявилися недостовірними. Водночас гіпертиреоз викликав достовірне (на 64 \%) підвищення рівня $\mathrm{H}_{2} \mathrm{~S}$ у сироватці крові щурів щодо тварин із ГГЦ. Встановлено, що паралельне введення L-тироксину щурам із ГГЦ протягом 21-ї доби призводило до зниження рівня ГЦ на 76 \% порівняно $з$ контрольною групою тварин. Концентрація цистеїну при введенні L-тироксину тваринам із ГГЦ достовірно зростала на 26 \% відносно щурів, у яких моделювали гіпертиреоз, та на $47 \%$ щодо інтактних тварин. Рівень $\mathrm{H}_{2} \mathrm{~S}$ при введенні L-тироксину тваринам, у яких моделювали ГГЦ, знижувався на 19 та 34 \% порівняно з інтактними тваринами і щурами з гіпертиреозом.

Встановлено, що експериментальний гіпотиреоз призводив до зростання концентрації ГЦ у 2,6 раза щодо контрольної групи тварин. За цих умов рівень цистеїнемії достовірно підвищувався на 40 та 89 \% порівняно 3 інтактними тваринами та групою щурів з експериментальною ГГЦ. Рівень $\mathrm{H}_{2} \mathrm{~S}$ достовірно (на $24 \%$ ) зменшувався відносно контрольної групи тварин. Паралельне введення мерказолілу щурам 3 експериментальною ГГЦ призводило до збільшення рівня ГЦ у 4,5 раза порівняно з інтактними тваринами та в 1,7 раза щодо групи тварин, у яких викликали гіпотиреоз. Паралельне введення мерказолілу щурам із ГГЦ спричиняло також підвищення концентрації цистеїну в 1,6 раза, при цьому рівень $\mathrm{H}_{2} \mathrm{~S}$ зменшувався в 1,7 раза порівняно з контрольною групою тварин.

У роботі [4] досліджено взаємозв'язок між рівнями ГЦ і тиреоїдних гормонів у сироватці крові 48 пацієнтів з післяопераційним гіпертиреозом. Автори зробили висновок, що зростання вмісту ГЦ у крові позитивно корелює з вмістом тироксину і може призводити до змін кардіометаболічних показників, водночас застосування замісної терапії левотироксином призводить до зниження вмісту ГЦ у крові.

Встановлено, що ензими окисного та кон'югаційного шляхів утилізації цистеїну в печінці щурів дуже чутливі до високої концентрації тіолактон-ГЦ (табл. 4). Введення препарату спричиняло зниження активності цих ензимів у печінці тварин. За умов ГГЦ зменшувалася швидкість окиснення цистеїну до цистеїнсульфрінату з участю Цдо порівняно з відповідними показниками в контрольній групі тварин, проте при статистичному аналізі дані виявилися недостовірними. Експериментальний гіпертиреоз викликав зростання активності ЦДО на 64 \% порівняно $з$ групою щурів, яким вводили тіолактон-ГЦ. Введення тваринам мерказолілу призводило до зниження активності ЦДО на $41 \%$ щодо інтактних тварин. Водночас при ГГЦ на 38 \% зменшувалась активність реакції кон'югації цистеїну 3 глутаматом з участю у-ГЦЛ порівняно з контрольною групою. Гіпертиреоз призводив до підвищення активності цього ензиму в печінці щурів у 3,5 раза відносно тварин із ГГЦ. Паралельне введення L-тироксину щурам із ГГЦ спричиняло достовірне (на 70 \%) зниження активності у-ГЦЛ порівняно з групою тварин 3 гіпертиреозом. Гіпотиреоз викликав протилежні зміни активності у-ГЦЛ, активність цього ензиму достовірно зростала на 62 \% щодо контрольної групи тварин та у 2,6 раза відносно щурів із ГГЦ. Паралельне введення мерказолілу тваринам із ГГЦ спричиняло зниження активності у-ГЦЛ на 69 \% порівняно зі щурами, в яких викликали гіпотиреоз. Встановлено, що тільки гіпертиреоз впливав на активність ензиму тіосульфаттрансорерази, вона достовірно підвищувалась на 92 \% щодо контрольної групи тварин. Активність сульфітоксидази зазнавала різнонаправлених змін. Гіпергомоцистеїнемія призводила до зменшення активності СО на 33 \%, водночас гіпоти-

Таблиця 4 - Активність (нмоль/хв·мг протеїну) ензимів циклу транссульфування в печінці щурів з різною фрункцією щитоподібної залози при гіпергомоцистеїнемії ( $M \pm m, n=8)$

\begin{tabular}{|c|c|c|c|c|c|c|}
\hline \multirow{5}{*}{ Показник } & \multicolumn{6}{|c|}{ Гррупа тварин } \\
\hline & \multirow{4}{*}{ інтактні } & модель ГГЦ & $\begin{array}{c}\text { модель } \\
\text { гіпертиреозу }\end{array}$ & $\begin{array}{c}\text { модель } \\
\text { гіпертиреозу+ } \\
\text { ГГЦ }\end{array}$ & $\begin{array}{c}\text { модель } \\
\text { гіпотиреозу }\end{array}$ & $\begin{array}{c}\text { модель } \\
\text { гіпотиреозу+ } \\
\text { ГГЦ }\end{array}$ \\
\hline & & \multicolumn{5}{|c|}{ час від початку введення, доби } \\
\hline & & тіолактон-ГЦ & L-тироксин & $\begin{array}{c}\text { L-тироксин } \\
\text { і тіолактон-ГЦ }\end{array}$ & мерказоліл & $\begin{array}{c}\text { мерказоліл } \\
\text { і тіолактон-ГЦ }\end{array}$ \\
\hline & & 28 & 21 & 28 & 21 & 28 \\
\hline ЦДО & $1,12 \pm 0,13$ & $0,88 \pm 0,08$ & $1,44 \pm 0,15^{\&}$ & $1,02 \pm 0,10$ & $0,66 \pm 0,07^{*}$ & $0,77 \pm 0,11$ \\
\hline у-ГЦЛ & $4,50 \pm 0,86$ & $2,77 \pm 0,12$ & $9,65 \pm 1,93^{\&}$ & $2,87 \pm 0,21^{\#}$ & $7,30 \pm 0,88^{\star \&}$ & $2,26 \pm 0,15^{\$}$ \\
\hline $\begin{array}{l}\text { Тіосульфрат- } \\
\text { трансорераза }\end{array}$ & $1,18 \pm 0,13$ & $0,78 \pm 0,12$ & $1,50 \pm 0,22^{\&}$ & $1,13 \pm 0,15$ & $1,11 \pm 0,25$ & $0,68 \pm 0,14$ \\
\hline $\mathrm{CO}$ & $3,77 \pm 0,30$ & $2,54 \pm 0,12^{*}$ & $4,33 \pm 0,31^{\&}$ & $3,25 \pm 0,14^{\& \#}$ & $3,11 \pm 0,42^{\&}$ & $1,33 \pm 0,10 * \& \$$ \\
\hline
\end{tabular}


реоз зумовлював її зростання на 70 \% відносно контрольної групи тварин. Паралельне введення L-тироксину щурам із ГГЦ спричиняло підвищення активності СО на 28 \% порівняно 3 тваринами з ГГЦ, водночас активність цього ензиму залишалась на 25 \% нижчою, ніж у щурів з гіпертиреозом. Гіпотиреоз, модельований мерказолілом, призводив до зниження активності СО на $22 \%$ відносно тварин із ГГЦ. Активність СО достовірно зменшувалась при введенні щурам із ГГЦ мерказолілу - на 65, 48 та 57 \% порівняно 3 контрольною групою тварин, щурами з ГГЦ і тваринами з гіпотиреозом відповідно.

ВИСНОВКИ. 1. Тривале введення тіолактон гомоцистеїну призводить до пригнічення активності ензимів утилізації ГЦ у печінці (БГМТ, S-AMS, S-АГГ), ензимів деградації цистеїну (ЦДО, у-ГЦЛ, СО) та ензимів синтезу $\mathrm{H}_{2} \mathrm{~S}$ (десульфуразна активність ЦБС, ЦГЛ), що викликає істотне зростання в сироватці крові рівня ГЦ, цистеїну і зменшення вмісту $\mathrm{H}_{2} \mathrm{~S}$.

2. За умов експериментального гіпертиреозу достовірно зростає активність ензимів циклу реметилування (БГMT, S-AMS, S-АГГ), десульфурування (ЦБС, ЦГЛ), посилюється окиснення цистеїну (ЦДО, у-ГЦЛ, СО), зменшується рівень ГЦ та цистеїну, збільшується вміст $\mathrm{H}_{2} \mathrm{~S}$ у крові. Введення L-тироксину тваринам із ГГЦ призводить до зниження активності ензимів циклу ре-

\section{СПИСОК ЛІТЕРАТУРИ}

1. Bhatia P. Homocysteine excess: delineating the possible mechanism of neurotoxicity and depression / P. Bhatia, N. Singh // Fundam. Clin. Pharmacol. -2015. 29, No. 6. - P. 522-528.

2. Ganguly P. Role of homocysteine in the development of cardiovascular disease / P. Ganguly, S. F. Alam // Nutr. J. - 2015. - 14. - P. 6

3. Lai W. K. Homocysteine-induced endothelial dysfunction / W. K. Lai, M. Y. Kan // Ann. Nutr. Metab. 2015. - 67, No. 1. - P. 1-12.

4. Effects of thyroid hormone withdrawal on metabolic and cardiovascular parameters during radioactive iodine therapy in differentiated thyroid cancer / J. H. An, K. H. Song, D. L. Kim [et al.] // Journal of International Medical Research. - 2017. - 45, No. 1. - P. 38-50.

5. Hyperthyroid heart disease / B. M. Fadel, S. Ellahham, M. D. Ringel [et al.] // Clinical Cardiology. - 2000. 23. - P. $402-408$

6. Franklyn J. A. Thyrotoxicosis / J. A. Franklyn, K. Boelaert // Lancet. - 2012. - 379. - P. 1155-1166. метилування (БГMT, S-AMS, S-АГГ), транссульфрування (ЦДО, у-ГЦЛ, СО) та десульфрурування (ЦБС, ЦГЛ), водночас спостерігають позитивну динаміку щодо зменшення вмісту ГЦ, цистеїну та зростання рівня $\mathrm{H}_{2} \mathrm{~S}$ у крові.

3. Стан гіпотиреозу призводить до зниження в печінці активності ензимів циклу реметилування (БГМT, S-AMS, S-АГГ) і процесів транссульфування (ЦБС, ЦГЛ, ЦАТ), що супроводжується збільшенням вмісту ГЦ і цистеїну та зниженням рівня $\mathrm{H}_{2} \mathrm{~S}$. Паралельне введення мерказолілу тваринам із ГГЦ спричиняє підвищення концентрації ГЦ у сироватці крові щурів, що є наслідком порушення реакцій циклу метилування (S-AMC, S-AГГ, БГМТ) і пригнічення процесу десульфурування (ЦБС, ЦГЛ, ЦАТ) у печінці тварин 3 експериментальною ГГЦ.

4. Збільшення вмісту ГЦ і цистеїну, зменшення рівня $\mathrm{H}_{2} \mathrm{~S}$ можуть бути вагомими фракторами ризику розвитку атеросклерозу, оксидативного стресу, ендотеліальної диссрункції та гіперкоагуляції при хворобах, що супроводжуються зниженням рівня тиреоїдних гормонів.

5. Отримані дані $\epsilon$ передумовою для подальших експериментальних досліджень, направлених на поліпшення розуміння механізмів фрормування патологічних станів, асоційованих з порушеннями обміну сірковмісних амінокислот при гіпергомоцистеїнемії і розладах функції щитоподібної залози, та оптимізації підходів до їх фрармакотерапії.
7. Vargas-Uricoechea $\mathrm{H}$. Effects of thyroid hormones on the heart / $\mathrm{H}$. Vargas-Uricoechea, A. Bonelo-Perdomo, C. H. Sierra-Torres // Clinica e investigacion en arteriosclerosis: Publicacion oficial de la Sociedad Espanola de Arteriosclerosis. - 2014. - 26. - P. 296-309.

8. High-normal thyroid function and risk of atrial fibrillation: The Rotterdam study / J. V. Heeringa, E. H. Hoogendoorn, W. M. Van der Deure [et al.] // Archives of Internal Medicine. - 2008. - 168. - P. 2219-2224.

9. The association between subclinical hyperthyroidism and blood pressure in a population-based study / H. Volzke, D. Alte, M. Dorr [et al.] // Journal of Hypertension. - 2006. - 24. - P. 1947-1953.

10. Thyroid peroxidase antibody is associated with plasma homocysteine levels in patients with Graves' disease / F. Li, G. Aji, Y. Wang [et al.] // Exp. Clin. Endocrinol. Diabetes. -2018. doi: 10.1055/a-0643-4692.

11. Evaluation of the interrelationships between thyroid function, autoimmunity, insulin resistance and lipid profile in Graves' disease / A. Carujo, C. Neves, 
J. S. Neves [et al.] // Revista Portuguesa De Endocrinologia Diabetes E Metabolismo. - 2017. - 12, No. 2. P. $142-150$.

12. Hyperhomocysteinemia, inflammation and autoimmunity/P. E. Lazzerini, P. L. Capecchi, E. Selvi [et al.] // Autoimmunity Reviews. - 2007. - 6. - P. 503-509.

13. Isguven P. Effects of thyroid autoimmunity on early atherosclerosis in euthyroid girls with hashimoto's thyroiditis / P. Isguven, Y. Gunduz, M. Kilic // Journal of Clinical Research in Pediatric Endocrinology. - 2016. - 8, No. 2. - P. 150-156.

14. Доклінічні дослідження лікарських засобів / за ред. О. В. Стефранова. - К. : Авіцена, 2001. - 528 с.

15. Stangl G. I. Homocysteine thiolactone-induced hyperhomocysteinemia does not alter concentrations of cholesterol and SREBP-2 target gene mRNAS in rats / G. I. Stangl // Exp. Biol. Med. (Maywood). - 2007. - 232, No. 1. - P. 81-87.

16. Нечипорук В. М. Метаболізм цистеїну при експериментальному гіпер- та гіпотиреозі в щурів / В. М. Нечипорук, М. М. Корда // Мед. та клініч. хімія. 2017. - 19, № 4 (73). - С. 32-40.

17. Chiang P. K. Activation of methionin for transmethylation. Purification of the S-adenosylmethionine synthetase of bakers' yeast and its separation into two forms / P. K. Chiang, G. L. Cantoni // J. Biol. Chem. 1977. - 252, No. 13. - P. 4506-4513.

18. Isa Y. Effect of vitamin $B_{6}$ deficiency on S-adenosylhomocysteine hydrolase activity as a target point for methionine metabolic regulation / Y. Isa, H. Tsuge, T. Hayakawa // J. Nutr. Sci. Vitaminol. - 2006. - 52, No. 5. - P. 302-306.

\section{REFERENCES}

1. Bhatia, P., \& Singh, N. (2015). Homocysteine excess: delineating the possible mechanism of neurotoxicity and depression. Fundam. Clin. Pharmacol, 29 (6), 522-528.

2. Ganguly, P., \& Alam, S.F. (2015). Role of homocysteine in the development of cardiovascular disease. Nutr. J., 14, 6.

3. Lai, W.K., \& Kan, M.Y. (2015). Homocysteine-induced endothelial dysfunction. Ann. Nutr. Metab., 67 (1), 1-12.

4. An, J.H., Song, K.H., \& Kim, D.L. (2017). Effects of thyroid hormone withdrawal on metabolic and cardiovascular parameters during radioactive iodine therapy in differentiated thyroid cancer. Journal of International Medical Research, 45, 1, 38-50.

5. Fadel, B.M., Ellahham, S., \& Ringel, M.D. (2000). Hyperthyroid heart disease. Clinical Cardiology, 23, 402-408.

6. Franklyn, J.A., \& Boelaert, K. (2012). Thyrotoxicosis. Lancet, 379, 1155-1166.

7. Vargas-Uricoechea, H., Bonelo-Perdomo, A., \& Sierra-Torres, C.H. (2014). Effects of thyroid hormones on the heart. Clinica e investigacion en arteriosclerosis:
19. Ericson L. E. Betaine-homocysteine methyltransferases III. The methyl donor specificity of the transferase isolated from pig liver / L. E. Ericson // Acta Chemica Scandinavica. - 1960. - 14. - P. $2127-$ 2134.

20. Dombkowski R. A. Hydrogen sulfide as an endogenous regulator of vascular smooth muscle tone in trout / R. A. Dombkowski, M. J. Russell, K. R. Olson // Am. J. Physiol. Regul. Integr. Comp. Physiol. - 2004. 286, No. 4. - P.678-685.

21. Orlowski M. Partial reaction by y-glutamylcysteine synthetase and evidence for an activated glutamate intermediate / M. Orlowski, A. Mrister // J. Biol. Chem. 1971. - 246, No. 23. - P. 7095-7105.

22. Gaitonde M. K. A spectrophotometric method for direct determination of cysteine in the presence of other naturally occuring amino acid / M. K. Gaitonde // Biochem. J. -1967 . - 104, No. 2. - P. 627-633.

23. Cohen H. J. Hepatic sulfite oxidase. Purification and properties / H. J. Cohen, I. Fridovich // J. Biol. Chem. 1971. - 246, No. 2. - Р. 359-366.

24. Визначення вмісту гідроген сульфіду в сироватці крові / Н. В. Заічко, Н. О. Пентюк, Л. О. Пентюк [та ін.]. // Вісн. наук. дослідж. - 2009. - № 1 (54). C. 29-32.

25. Expression of hydrogen sulfide synthases and Hh signaling pathway components correlate with the clinicopathological characteristics of papillary thyroid cancer patients / Y. Xu, N. Ma, P. Wei [et al.] // International journal of clinical and experimental pathology. - 2018. 11, No. 3. - P. 1818-1824.
Publicacion oficial de la Sociedad. Espanola de Arteriosclerosis, 26, 296-309.

8. Heeringa, J.V., Hoogendoorn, E.H., \& Van der Deure, W.M. (2008). High-normal thyroid function and risk of atrial fibrillation: The Rotterdam study. Archives of Internal Medicine, 168, 2219-2224.

9. Volzke, H., Alte, D., \& Dorr, M. (2006). The association between subclinical hyperthyroidism and blood pressure in a population-based study. Journal of Hypertension, 24, 1947-1953.

10. Li, F., Aji, G., \& Wang, Y. (2018). Thyroid peroxidase antibody is associated with plasma homocysteine levels in patients with Graves' disease. Exp. Clin. Endocrinol. Diabetes. doi: 10.1055/a-0643-4692.

11. Carujo, A., Neves, C., \& Neves, J.S. (2017). Evaluation of the Interrelationships between thyroid function, autoimmunity, insulin resistance and lipid profile in Graves' disease. Revista Portuguesa De Endocrinologia Diabetes E Metabolismo, 12 (2), 142-150.

12. Lazzerini, P.E., Capecchi, P.L., \& Selvi, E. (2007). Hyperhomocysteinemia, inflammation and autoimmunity. Autoimmunity Reviews, 6, 503-509. 
13. Isguven, P., Gunduz, Y., \& Kilic, M. (2016). Effects of thyroid autoimmunity on early atherosclerosis in euthyroid girls with Hashimoto's thyroiditis. Journal of Cical Research in Pediatric Endocrinology, 8 (2), 150-156.

14. Stefanov, O.V. (Ed.). (2001). Doklinichni doslidzhennia likarskykh zasobiv [Pre-clinical studies of medical drugs]. Kyiv. Avitsena [in Ukrainian].

15. Stangl, G.I. (2007). Homocysteine thiolactoneinduced hyperhomocysteinemia does not alter concentrations of cholesterol and SREBP-2 target gene mRNAS in rats. Exp. Biol. Med., 232 (1), 81-87.

16. Nechyporuk, V.M., \& Korda, M.M. (2017). Metabolizm tsysteinu pry eksperymentalnomu hiper- ta hipotyreozi v shchuriv [Metabolism of cysteine in experimental hyper- and hypothyroidism in rats]. Medychna ta klinichna khimiia - Medical and Clinical Chemistry, 19 (4), 32-40 [in Ukrainian].

17. Chiang, P.K., \& Cantoni, G.L. (1977). Activation of methionin for transmethylation. Purification of the S-adenosylmethionine synthetase of bakers' yeast and its separation into two forms. J. Biol. Chem., 252 (13), 4506-4513.

18. Isa, Y., Tsuge, H., \& Hayakawa, T. (2006). Effect of vitamin $B_{6}$ deficiency on S-adenosylhomocysteine hydrolase activity as a target point for methionine metabolic regulation. J. Nutr. Sci. Vitaminol., 52 (5), 302306.

19. Ericson, L.E. (1960). Betaine-homocysteine methyltransferases III. The methyl donor specificity of the transferase isolated from pig. Acta Chemica Scandinavica, 14, 2127-2134.

20. Dombkowski, R.A., Russell, M.J., \& Olson, K.R. (2004). Hydrogen sulfide as an endogenous regulator of vascular smooth muscle tone in trout. Am. J. Physiol. Regul. Integr. Comp. Physiol, 286 (4), 678-685.

21. Orlowski, M., \& Mrister, A. (1971). Partial reaction by $\mathrm{y}$-glutamylcysteine synthetase and evidence for an activated glutamate intermediate. J. Biol. Chem., 246 (23), 7095-7105.

22. Gaitonde, M.K. (1967) A spectrophotometric method for direct determination of cysteine in the presence of other naturally occuring amino acid. Biochem. J., 104 (2), 627-633.

23. Cohen, H.J., \& Fridovich, I. (1971). Hepatic sulfite oxidase. Purification and properties. J. Biol. Chem., 246 (2), 359-366.

24. Zaichko, N.V., Pentiuk, N.O., Pentiuk, L.O., Melnyk, A.V., \& Andrushko, I.I. (2009). Vyznachennia vmistu hidrohen sulfidu $v$ syrovattsi krovi [Determination of hydrogen sulfide in blood serum]. Visnyk naukovykh doslidzhen - Bulletin of Scientific Research, 1, 29-32 [in Ukrainian].

25. Xu, Y., Ma, N., \& Wei, P. (2018). Expression of hydrogen sulfide synthases and Hh signaling pathway components correlate with the clinicopathological characteristics of papillary thyroid cancer patients. International Journal of Clinical and Experimental Pathology, 11 (3), 1818-1824.

В. М. Нечипорук ${ }^{1}$, Н. В. Заичко ${ }^{1}$, А. В. Мельник ${ }^{1}$, Е. Б. Струтинская ${ }^{1}$, М. М. Корда ${ }^{2}$ ВИННИЦКИЙ НАЦИОНАЛЬНЫЙ МЕДИЦИНСКИЙ УНИВЕРСИТЕТ ИМЕНИ Н. И. ПИРОГОВА ТЕРНОПОЛЬСКИЙ ГОСУДАРСТВЕННЫЙ МЕДИЦИНСКИЙ УНИВЕРСИТЕТ ИМЕНИ И. Я. ГОРБАЧЕВСКОГО

\section{ОСОБЕННОСТИ ВЛИЯНИЯ ГИПЕРГОМОЦИСТЕИНЕМИИ НА МЕТАБОЛИЗМ СЕРОСОДЕРЖАЩИХ АМИНОКИСЛОТ В ПЕЧЕНИ КРЫС С РАЗЛИЧНОЙ ФУНКЦИЕЙ ЩИТОВИДНОЙ ЖЕЛЕЗЫ}

\section{Резюме}

Вступление. Гомоцистеин (ГЦ) - серосодержащая аминокислота, которая образуется при нормальном биосинтезе аминокислот метионина и цистеина. Известно, что гормоны щитовидной железы оказывают значительное влияние на фрункции сердечно-сосудистой системы. Высокий риск развития сердечно-сосудистых заболеваний существует у пациентов с гипергомоцистеинемией (ГГЦ). Уровень ГЦ у больных с гипотиреозом выше, чем у здоровых людей. В то же время непонятно, связано ли развитие сердечно-сосудистых заболеваний у пациентов с патологией щитовидной железы с изменениями уровня в крови ГЦ.

Цель исследования -установить влияние экспериментальной гипергомоцистеинемии на процессы обмена серосодержащих аминокислот у животных с гипер- и гипотиреозом.

Методы исследования. Исследование выполнено на белых крысах-самцах, у которых моделировали гипергомоцистеинемию, гипер- и гипотиреоз. В печени определяли активность S-аденозилметионинсинтетазы (S-AMS), S-аденозилгомоцистеингидролазы (S-AГГ), бетаингомоцистеинметилтрансферазы (БГМТ), цистатионин- $\beta$-синтазы (ЦБС), цистатионин-у-лиазы (ЦГЛ), цистеинаминотрансферазы (ЦАТ), у-глутамилцистеинлигазы (у-ГЦЛ), цистеиндиоксигеназы (ЦДО), сульфитоксидазы (СО), в сыворотке крови - общее содержание ГЦ, цистеина, $\mathrm{H}_{2} \mathrm{~S}$. 
Результаты и обсуждение. Длительная ГГЦ приводила к угнетению активности энзимов утилизации ГЦ в печени (БГМT, S-AMS, S-АГГ), деградации цистеина (ЦДО, у-ГЦЛ, CO) и синтеза $\mathrm{H}_{2} \mathrm{~S}$ (десульфуразная активность ЦБС, ЦГЛ), что вызывало существенное повышение в сыворотке крови уровня ГЦ, цистеина и уменьшение содержания $\mathrm{H}_{2} \mathrm{~S}$. Гипертиреоз обусловливал возрастание активности большинства энзимов цикла реметилирования (БГМT, S-AMS, S-АГГ), десульфрирования (ЦБС, ЦГЛ), усиление окисления цистеина (ЦДО, у-ГЦЛ, СО), уменьшение уровня ГЦ и цистеина, увеличение содержания $\mathrm{H}_{2} \mathrm{~S}$ в крови. Параллельное введение L-тироксина животным с ГГЦ приводило к снижению активности энзимов цикла реметилирования (БГМT, S-AMS, S-АГГ), транссульфрурирования (ЦДО, у-ГЦЛ, СО) и десульфрирования (ЦБС, ЦГЛ), одновременно наблюдали положительную динамику относительно уменьшения содержания ГЦ, цистеина и возрастания уровня $\mathrm{H}_{2} \mathrm{~S}$ в крови. Гипотиреоз вызывал снижение в печени активности энзимов цикла реметилирования (БГМТ, S-AMS, S-AГГ) и процессов транссульфурирования (ЦБС, ЦГЛ, ЦАТ), увеличение содержания ГЦ, цистеина и уменьшение уровня $\mathrm{H}_{2} \mathrm{~S}$. Параллельное введение мерказолила животным с ГГЦ обусловливало возрастание концентрации ГЦ в сыворотке крови крыс, что является следствием нарушения реакций цикла метилирования (S-AMC, S-AГГ, БГMT) и десульфирования (ЦБС, ЦГЛ, ЦАТ) в печени животных с экспериментальной ГГЦ.

Выводы. Увеличение содержания ГЦ и цистеина, уменьшение уровня $\mathrm{H}_{2} \mathrm{~S}$ могут быть весомыми фракторами риска развития атеросклероза, оксидативного стресса, эндотелиальной дисфрункции и гиперкоагуляции при болезнях, сопровождающихся снижением уровня тиреоидных гормонов. Полученные данные являются предпосылкой для дальнейших экспериментальных исследований, направленных на улучшение понимания механизмов фрормирования патологических состояний, ассоциированных с нарушениями обмена серосодержащих аминокислот при гипергомоцистеинемии и расстройствах фрункции щитовидной железы, и оптимизации подходов к их фрармакотерапии.

КЛЮЧЕВЫЕ СЛОВА: тиреоидные гормоны; серосодержащие аминокислоты; цикл реметилирования; путь транссульфурирования; гомоцистеин; цистеин; гидроген сульфид.

V. M. Nechiporuk ${ }^{1}$, N. V. Zaichko' ${ }^{1}$ A. V. Melnik ${ }^{1}$, O. B. Strutynska ${ }^{1}$, M. M. Korda ${ }^{2}$ M. PYROHOV VINNYTSIA NATIONAL MEDICAL UNIVERSITY1 I. HORBACHEVSKY TERNOPIL STATE MEDICAL UNIVERSITY²

\section{FEATURES OF INFLUENCE OF HYPERHOMOCYSTEINEMIA ON THE METABOLISM OF SULFUR-CONTAINING AMINO ACIDS IN THE LIVER OF RATS WITH VARIOUS FUNCTIONS OF THYROID GLAND}

\section{Summary}

Introduction. Homocysteine (Hcy) is a sulfur-containing amino acid that is formed during normal biosynthesis of methionine and cysteine amino acids. It is known that thyroid hormones have a significant effect on the function of the cardiovascular system. Patients with hyperhomocysteinemia (HHC) have a high risk of formation of cardiovascular diseases. The level of Hcy in patients with hypothyroidism is higher than in healthy people. At the same time, it is unclear whether the development of cardiovascular diseases in patients with thyroid gland pathology is associated with changes in the content of Hcy in blood.

The aim of the study - to determine the effect of experimental hyperhomocysteinemia on the metabolism of sulfur-containing amino acids in animals with hyper- and hypothyroidism.

Research Methods. The study was performed on white male rats, which were simulated hyperhomocysteinemia, hyper- and hypothyroidism. The activity of S-adenosylmethionine synthetase (S-AMS), S-adenosylhomocysteine hydrolase (S-AHH), betaine-homocysteine methyltransferase (BHMT), cystathionine- $\beta$-synthase (CBS), cystathionine$y$-lyase (CSE), cysteine aminotransferase (CAT), y-glutamylcysteine ligase ( $y$-GCL), cysteine dioxygenase (CDO), sulfite oxidase (SO) was determined in the liver; content of Hcy, cysteine, $\mathrm{H}_{2} \mathrm{~S}$ was determined in the serum.

Results and Discussion. Long-term HHC leads to inhibition of the activity of enzymes utilizing Hcy in the liver (BHMT, S-AMS, S-AHH), cysteine deterioration (CDO, $y-G C L, S O$ ) and $\mathrm{H}_{2}$ S synthesis (desulfurase activity of CBS, CSE), which led to a significant increase in serum blood levels of Hcy, cysteine and a decrease in the content of $\mathrm{H}_{2}$ S. Hyperthyroidism leads to an increase in the activity of most enzymes of the remethylation cycle (BHMT, S-AMS, $S-A H H)$, desulfuration cycle (CBS, CSE), increased oxidation of cysteine (CDO, $y-G C L, S O)$ a decrease in the level of Hcy and cysteine, growth of the level of $\mathrm{H}_{2} \mathrm{~S}$ in the blood. Parallel administration of L-thyroxine to animals with 
$H H C$ led to a decrease in the activity of enzymes of the remethylation cycle (BHMT, S-AMS, S-AHH), transsulfuration (CDO, $y-G C L, S O$ ) and desulfuration (CBS, CSE), at the same time there was a positive trend in reducing Hcy, cysteine and an increase in the level of $\mathrm{H}_{2} \mathrm{~S}$ in the blood. Hypothyroidism led to a decrease in the liver activity of the enzyme cycle remethylation (BHMT, S-AMS, S-AHH) and transsulfuration processes (CBS, CSE, CAT), an increase in the content of Hcy and cysteine and a decrease in the level of $\mathrm{H}_{2} \mathrm{~S}$. Parallel administration of mercazolile to animals with $\mathrm{HHC}$ led to an increase in the concentration of Hcy in the blood serum of rats, is a consequence of impaired methylation cycle reactions (S-AMS, S-AHH, BHMT) and desulfuration (CBS, CSE, CAT) in liver of animals with experimental HHC.

Conclusions. A high concentrations of Hcy and cysteine, a decreasing level of $\mathrm{H}_{2} \mathrm{~S}$ in hypothyroidism can be significant risk factors for the development of atherosclerosis, oxidative stress, endothelial dysfunction and hypercoagulation in diseases accompanied by low levels of thyroid hormones. Our findings are a prerequisite for further experimental studies, which will improve the understanding of the mechanisms of formation of pathological conditions associated with impaired metabolism of sulfur-containing amino acids at hyperhomocysteinemia with different thyroid functions, and optimize approaches for their pharmacotherapy.

KEY WORDS: thyroid hormones; sulfur-containing amino acids; remethylation cycle; transsulfuration pathway; homocysteine; cysteine; hydrogen sulfide.

Отримано 10.01.19

Адреса для листування: В. М. Нечипорук, Вінницький національний медичний університет імені М. І. Пирогова, вул. Пирогова, 56, Вінниця, 21018, Україна, e-mail: nechiporuk@vnmu.edu.ua. 